\title{
Assessing the public recreational space in the urban park from the psychological and behavioral aspects, a case study of Quyuan Park, Hangzhou, China
}

\author{
Chen $\mathrm{Bo}^{\mathrm{a}}$, Lu Shan ${ }^{\mathrm{b}}$ and Hu Shaoqing ${ }^{\mathrm{c}}$
}

School of Civil Engineering and Architecture, Zhejiang Sci-Tech University, Hangzhou, China

abochen2008@126.com, blushan516@163.com, 'shaoqinghu@163.com

Keywords: urban park; open space; facility; comprehensive assessment

\begin{abstract}
This paper presented results of an attempt to carry out a comprehensive assessment of public recreational space in an urban park, the Quyuan Park in Hangzhou city, China, from the psychological and behavioral aspects. Survey was done on the unit space to get the physical character, and enquiry was done to the users of the unit spaces. The enquiry was composed of an item of users' cognitive assessment in terms of psychological aspect, and an item of users' activity pattern in terms of carrying-out aspect. The following results were gained from the research: 1) Overall, the form of the unit space making up the parks existing in the urban area was found to be a user-oriented type, and its availability became an important assessment factor with this reflected. 2). It was found that the recreational value of the forest was low in comparison with that of the unit space of the facilities, the free open space and the waterfront of open space. 3). Arbors developed in the woodland, whose assessed value was relatively low, but the feelings of luxuriant forest whose forest floor was arranged and arbors were developed enhanced its value, and the tall herbaceous-forest preventing users from using the forest degraded its value remarkably. 4) The important task in the free open space included the setting of space size and topographic slant, the introduction of ground-cover vegetation and its maintenance. 5) The important task in the waterfront space included water behavior, embankment form and its material. 6) The important task in the forest included the planting design and management techniques relating to the composition of vegetation, such as the height and stand density of arbors, and cover type. 7) The unit space of the facilities becomes the secondary existence supporting the open space in the unit space. 8) Because the form of use was restricted according to the character of facilities regardless of the physical character in the selection of facilities, consideration of its usability become the important task.
\end{abstract}

\section{Introduction}

Public space is and has been an integral part of communities for centuries. It serves as a location for people to meet, relax, and exchange ideas. Historically, public recreational space has been the infrastructure for physical health and contemplative relaxation. To understand the importance of public space, it is vital to know what constitutes a public area. One definition of public space, states "a place where anyone can come without paying entrance or other fee" ${ }^{[1]}$. Typical examples are most roads, including pavements, and public parks, such as the parks around the West Lake in Hangzhou city, China.

While the process of varying the spaces for the outdoor recreation is being carried out, the various spaces available in the urban area possess not only common features required, but also other characters which are different in contents. Studies that treat collectively public recreational spaces are seldom in China. It can be considered that the object of recreational activities is the various unit spaces which form public recreational spaces, but such studies definitely are concerned with matters that can rarely be seen. Assessing the value of recreation is being tried in terms of human's reactive action on environments available. However, many studies are approached either from the psychological aspects or from the behavioral aspect ${ }^{[2-6]}$. It's hard to find any example of research approached collectively from both of the psychological and behavioral aspects. This research dealt 
with outdoor recreational spaces, and was in the series of studies that assessed the value of recreation out of the physical character of environments available and human being's reactive action of utility aspect.

This study dealt with the problems described previously, carried out the research concerned with public recreational spaces which form the parks in urban areas, and approached collectively users' response from both users' cognitive assessment and users' activity pattern. In addition, we carried out this research for the purpose of trying to show the directions for preparation techniques and management of recreational activity pattern and public recreational spaces in the urban park. It also was envisaged to provide theory and information so as to guide the planning and design of public recreational space in the urban park.

\section{Methods}

Study area. The area of study was Quyuan Park in Hangzhou city, Zhejiang Province, China, a real public space with no entry fee, which had an area of 28.4 hectares. Quyuan Park which features in lotus ranks the 2nd of Top Ten View of the West Lake in Hangzhou city just after Spring Dawn at Su Causeway. In Southern Song Dynasty, Quyuan Courtyard was an official vinery which was located on the bank of the West Lake beside the Hongcun Bridge on the Linyin Road where many lotuses were planted. In summer breezes, the air was scented with delicate fragrance of lotus intermingled with the tasteful bouquet of wine. However, the courtyard was very much neglected and the nearby lake silted up. It became a small garden with a small pavilion, a veranda and a few lotus flowers planted in the water in front. Starting from 1983, an extension project has been under way to develop it to a huge park. Currently, the park includes five sections: Yue Lake, Bamboo Garden, Lotus Garden, Winding Garden and Lakeside Forest. Therefore it is a very popular attraction for the tourists with General Yuefei’s Tomb, Guo’s Villa and Hangzhou Botanical Garden around.

Classification of the spaces surveyed. The public recreational spaces surveyed in this research,which are located in the Quyuan Park, are classified into open spaces and facilities. Open spaces were subclassified into three types (i.e. forest, free open space and waterfront). Each of them has 3 or 5 subtypes, so the open spaces include eleven subtypes. Facilities system were subclassified into eight types of cultural place, sightseeing place, education facility, resting facilities, amusement facilities, facilities for artificial landscape, play lot, and barbecue lot, and set up a total of nineteen unit spaces as spaces to survey. And each of the spaces, as spaces subjucted to survey, has a different physical character.

The psychological research of the park users. Enquiries were done by two or three surveyors on average at each space. It was composed of an item of users' cognitive assessment in terms of psychological aspect and an item of users' activity pattern in terms of carrying-out aspect.

The behavioral research of the park users. The assessment of users' activity pattern is enquiried. It was thought that each of the unit space of open spaces and facilities had its own purpose intensively, so different questionnaire items were set up according it.

\section{Results and analyses}

Enquiry was done to the users of the park concerning the nineteen unit spaces of the open space and facilities in Quyuan Park. Data from this enquiry was used to clarify each feature of uses' collative assessment and activity pattern, show the mutual relation between the physical and assessment character of each unit space, and inquire into physical factor on recreational value and assessment of each unit space.

Respondents. Five hundred respondents were randomly approached at the site and attempted the survey. And 427 respondents managed to complete the questionnaire. It is this data that was used and reported in this study, while the incomplete data were omitted. Table l shows the users' character. The results of the on-site surveys are shown in Table 2 and Table 3. 
Table 1 Summery of the uses' social variables

\begin{tabular}{|c|c|}
\hline Social variables & Classes \\
\hline Sex & males $44 \%$; females $56 \%$. \\
\hline Ages & $\begin{array}{c}\text { a. under } 20 \text { years } 9 \% \text {; b. } 21-30 \text { years } 24 \% \text {; c. } 31-40 \text { years } 33 \% \text {; d. } 41-50 \text { years } \\
18 \% \text {; e. } 51-60 \text { years } 10 \% \text {; } 6 \text { : over } 61 \text { years } 6 \% \text {. }\end{array}$ \\
\hline Types & $\begin{array}{c}\text { a. } 1 \text { person } 10 \% \text {; b. } 2-3 \text { persons } 59 \% \text {; c. } 4-5 \text { persons } 24 \% \text {; d. over } 6 \text { persons } \\
7 \% \text {. }\end{array}$ \\
\hline Residence & $\begin{array}{l}\text { a. Hangzhou city 58\%; b. Zhejiang province (not a.) } 19 \% \text {; c. out of Zhejiang } \\
\text { province } 23 \% \text {. }\end{array}$ \\
\hline $\begin{array}{l}\text { Residence time in } \\
\text { Hangzhou }\end{array}$ & a. less than a year $47 \%$; b. more than a year $53 \%$. \\
\hline $\begin{array}{l}\text { Number of visits to } \\
\text { the park }\end{array}$ & a. First visit 36\%; b. More than one visits 64\%. \\
\hline
\end{tabular}

\section{Table 2 Physical character of open spaces in the Quyuan Park}

\begin{tabular}{|c|c|c|c|c|c|c|c|c|c|c|c|}
\hline \multirow[b]{3}{*}{ No. } & \multirow{3}{*}{$\begin{array}{l}\text { Name } \\
\text { of the } \\
\text { subtype }\end{array}$} & \multirow{3}{*}{$\begin{array}{c}\text { Sl } \\
\text { ope } \\
\left({ }^{\circ}\right)\end{array}$} & \multicolumn{9}{|c|}{ Vegetation } \\
\hline & & & \multicolumn{4}{|c|}{ Arbor } & \multicolumn{2}{|c|}{ Shrub } & \multicolumn{3}{|c|}{ Forest floor } \\
\hline & & & $\begin{array}{c}\text { Cover } \\
\text { degre } \\
\mathrm{e}\end{array}$ & $\begin{array}{l}\text { Height } \\
\text { (m) }\end{array}$ & $\mathrm{SD}^{*}$ & $\begin{array}{l}\text { Forest } \\
\text { type }\end{array}$ & $\begin{array}{c}\text { Cover } \\
\text { degre } \\
\mathrm{e}\end{array}$ & $\begin{array}{l}\text { Height } \\
\text { (m) }\end{array}$ & $\begin{array}{l}\text { Cover } \\
\text { type }\end{array}$ & $\begin{array}{c}\text { Cover } \\
\text { degre } \\
\mathrm{e}\end{array}$ & $\begin{array}{l}\text { Height } \\
\text { (m) }\end{array}$ \\
\hline 1 & Forest A & flat & 5 & 12.5 & 8 & $\begin{array}{l}\text { mixed } \\
\text { stand }\end{array}$ & + & 4.3 & bare & - & - \\
\hline 2 & Forest B & flat & 3 & 8.4 & 6 & $\begin{array}{l}\text { mixed } \\
\text { stand }\end{array}$ & 1 & 1.2 & grass & 5 & 51 \\
\hline 3 & Forest C & flat & 3 & 13.2 & 2 & $\begin{array}{l}\text { even-aged } \\
\text { forest }\end{array}$ & - & - & lawn & 5 & 23 \\
\hline 4 & Forest D & flat & 5 & 12.5 & 8 & $\begin{array}{c}\text { even-aged } \\
\text { forest }\end{array}$ & 2 & 2.5 & bare & - & - \\
\hline 5 & Forest E & flat & 3 & 11.6 & 7 & $\begin{array}{l}\text { mixed } \\
\text { stand }\end{array}$ & 1 & 2.5 & grass & 5 & 57 \\
\hline 6 & $\begin{array}{c}\text { Free open } \\
\text { space A }\end{array}$ & 3.4 & + & 9.7 & $<1$ & $\begin{array}{l}\text { mixed } \\
\text { stand }\end{array}$ & - & - & lawn & 5 & 5 \\
\hline 7 & $\begin{array}{c}\text { Free open } \\
\text { space B }\end{array}$ & flat & + & 12.6 & $<1$ & $\begin{array}{l}\text { mixed } \\
\text { stand }\end{array}$ & + & 2.0 & lawn & 5 & 5 \\
\hline 8 & $\begin{array}{c}\text { Free open } \\
\text { space C }\end{array}$ & flat & + & 9.4 & $<1$ & $\begin{array}{l}\text { mixed } \\
\text { stand }\end{array}$ & + & 4.5 & lawn & 4 & 5 \\
\hline 9 & $\begin{array}{c}\text { Waterfront } \\
\text { A }\end{array}$ & 1.7 & + & 9.0 & $<1$ & $\begin{array}{l}\text { mixed } \\
\text { stand }\end{array}$ & + & 0.8 & lawn & 5 & 5 \\
\hline 10 & $\begin{array}{c}\text { Waterfront } \\
\text { B }\end{array}$ & flat & 1 & 9.5 & 1 & $\begin{array}{l}\text { mixed } \\
\text { stand }\end{array}$ & + & 1.5 & lawn & 4 & 5 \\
\hline 11 & $\begin{array}{c}\text { Waterfront } \\
\text { C }\end{array}$ & flat & + & 8.3 & $<1$ & $\begin{array}{c}\text { mixed } \\
\text { stand }\end{array}$ & + & 4.7 & lawn & 4 & 5 \\
\hline
\end{tabular}

*SD: Stand density (number of tree per $100 \mathrm{~m}^{2}$ )

Table 3 Physical character of recreational facilities in the Quyuan Park

\begin{tabular}{cccccc}
\hline No. & Type of facilities & $\begin{array}{c}\text { Main function of } \\
\text { facilities }\end{array}$ & $\begin{array}{c}\text { Location condition } \\
\text { around }\end{array}$ & $\begin{array}{c}\text { Forest type } \\
\text { around }\end{array}$ & Cover type \\
\hline 12 & Cultural place & $\begin{array}{c}\text { Chinese traditional } \\
\text { garden }\end{array}$ & $\begin{array}{c}\text { artificial landscape } \\
\text { space } \\
\text { with arbor planting } \\
\text { unmovable garden } \\
\text { space }\end{array}$ & mixed stand & $\begin{array}{c}\text { lawn \& } \\
\text { ground cover }\end{array}$ \\
13 & $\begin{array}{c}\text { Education } \\
\text { facilities }\end{array}$ & Museum & $\begin{array}{c}\text { mand } \\
\text { set up on the ground }\end{array}$ & secondary & barement \\
\hline
\end{tabular}




\begin{tabular}{|c|c|c|c|c|c|}
\hline & & pavilion & & forest & \\
\hline 15 & Resting facilities & $\begin{array}{l}\text { Rest house \& } \\
\text { convenience } \\
\text { facilities }\end{array}$ & $\begin{array}{l}\text { pond attached to } \\
\text { large building }\end{array}$ & mixed stand & bare \\
\hline 16 & $\begin{array}{l}\text { Amusement } \\
\text { facilities }\end{array}$ & Little platform & near by entrance & & \\
\hline 17 & $\begin{array}{c}\text { Facilities for } \\
\text { artificial } \\
\text { landscape }\end{array}$ & $\begin{array}{c}\text { Fountain place } \& \\
\text { pond }\end{array}$ & near by entrance & mixed stand & pavement \\
\hline 18 & Play lot & Play lot & set up on the ground & mixed stand & pavement \\
\hline 19 & Barbecue lot & Barbecue lot & with arbor planting & mixed stand & bare \& lawn \\
\hline
\end{tabular}

Estimation of recreation in terms of users' cognitive assessment. Figure 1 shows each unit space on two dimensional coordinate by use of principal component scores of each unit space. We took in all up to the second principal component whose cumulation proportion was above eighty percent.

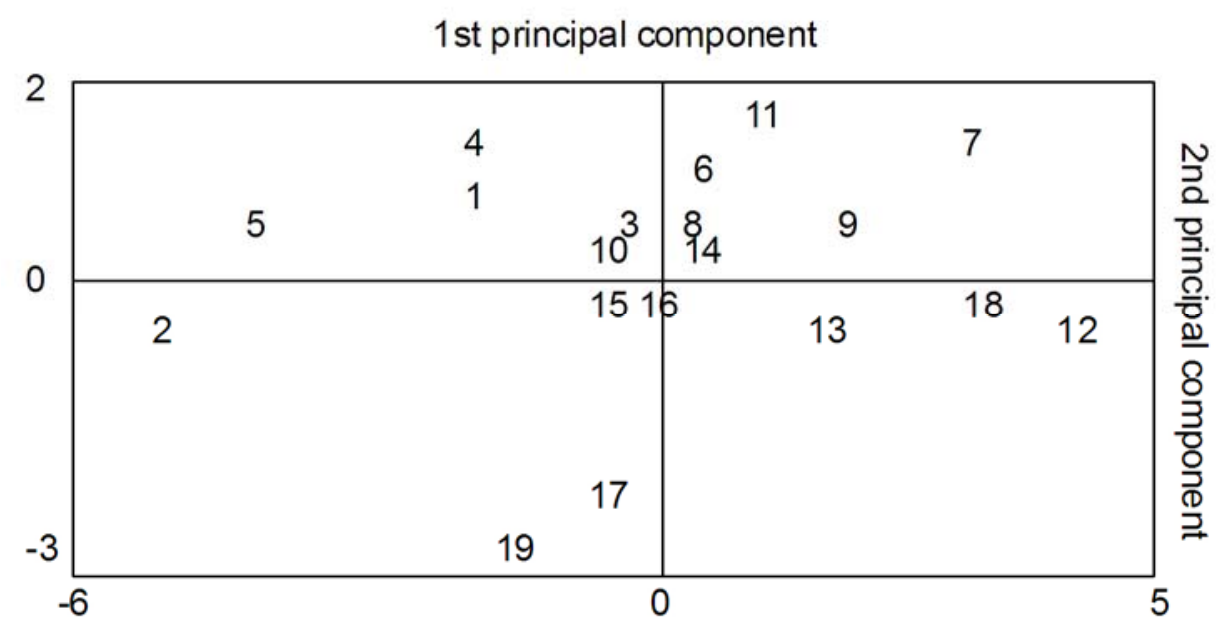

Fig. 1 Users' cognitive assessment

Considering the first principal component from Figure 1, it was observed that the assessment value of cultural facilities was the highest value. Play lot and free open space B were high values. Waterfront $A$ and $C$ and educational facilities were a little high value. On the other hand, forest $B$ was the lowest value. Forest $\mathrm{E}$ had been rather low, and forest $\mathrm{A}$ and $\mathrm{D}$ and barbecue lot were also a little low value. Free open space A and C, forest C, resting facilities, waterfront B, amusement facilities, facilities for artificial landscape, and sightseeing place were moderate values.

Looking at the second principal component results from Figure 1, waterfront $C$ was the highest assessment value. Forest $A$ and $D$ and free open space $A$ and $B$ were high value. Forest $C$ and $E$, free open space $\mathrm{C}$ and waterfront $\mathrm{A}$ were a little high value. On the other hand, barbecue lot was the lowest value. Facilities for artificial landscape were rather low. Amusement facilities, play lot and resting facilities, waterfront $\mathrm{B}$, forest $\mathrm{B}$, cultural space, educational facilities and sightseeing place were moderate values.

With respect to the value of recreation in each unit space from the results interpreted, which was based on classifying each unit space, it was revealed that the value of forest was lower than unit spaces of facilities, free open space and waterfront. From this observation, we concluded that outdoor recreation space in urban areas is user-oriented space, and each of the highly valuable unit spaces ranges from their moderate value to their high value in response to the physical character of unit space. Overall, the value of unit space in open space system was higher than facilities.

Looking at the recreational value of each unit spaces and physical characters related to the assessment results interpreted, and correlation among each unit space, we could get following results. Firstly, the unit space located in the most valuable group was Chinese traditional garden which was classified into cultural place and luxuriant forest, a play lot with various playing establishments, and 
a large free open space covered with lawn and surrounded with luxuriant forest. Therefore, degree of freedom concerned with utility and blending with nature improved the overall agreeableness. Secondly, the unit space belonging to the highly valuable group were reported, such as museums classified into educational facilities with arbor planting unmovable garden space, waterfront with lawn spreading out around the artificial stream looking natural, and small waterfront with lawn adjacent to a natural pond. Blending with nature improves the comprehensive comfortableness, but limitation degrades its recreational value because of lack of utility activities. Thirdly, the unit space belonging to the moderate group are sightseeing facilities set up on the ground, resting facilities attached to large buildings, amusement facilities, facilities for artificial landscape like a water fountain, barbecue lot arranged disorderly in rectangular passage space, waterfront with artificial embankment form, a free open space covered largely with lawn and sloped slowly, a small free space around the entrance of the park, and forest plainly covered lawn and its stand density less than two per $100 \mathrm{~m}^{2}$. Devaluation comes from dominance of artificial factor, figure and scale of space and limitation of utilizing because of slope and forest. Every group with low or extremely low value in assessment has a composition of forest and its recreational value comes out differently in accordance with forest structure. In other words, the cover degree and stand density of arbor layer is high. The forest in which arbor layer was developed and possessed orderly luxuriant forest space had slightly higher recreational value. The forest whose stand density was high, but the cover degree and the height of arbor layer were low (which was immature), possessed tall grass type had very low recreational value. Stand density more than five per $100 \mathrm{~m}^{2}$ was thought to restrain utilization of the forest, thus the recreational value went down. The feeling of luxuriant forest, however, raised the recreational value a little bit, and the tall herbaceous forest prevented users from using the forest, degrading its value remarkably.

Assessment of recreation in terms of users' activity pattern. The Dual Scaling Method was used to assess recreation in terms of users' activity pattern. The unit space of system and each item of users' activity pattern are shown on the two dimensional coordinate in order of each item of unit space and users' activity pattern which were obtained from the results interpreted by use of dual scaling with the number of responders on users' activity pattern of the unit spaces in the open space and facilities, and showing the unit space and users' activity patterns are divided into four groups by cluster analysis. The cumulation proportion was $75.6 \%$ for open space system and $86.2 \%$ for facilities system from the results, by dual scaling up to the second optimal scale.

Eleven unit spaces of open spaces were divided into four groups. Group A was for walking and jogging, hiking and climbing, passing, education of natural environment, and was a passage type of space. This group included forest A, B, D and E. Group B was the natural contact type of space, which was strongly only for natural contact use. This group included waterfront $C$. Group $C$ was the multi-functional use type of space for rest and picnic. This group included free open space A and C, and waterfront A and B. Group D was the use space of dynamic activity. This group included forest C and free open space B.

Eight unit spaces of facilities were divided into four groups. Group A was educational type of utilizable space which was for education. This group included educational facilities. Group D was amusement type of utilizable space which was for outdoor amusement. The group A and D were commonly composed of single use purpose and single use space, so that this was a unit space of facilities which had a strong purpose of utilizing. On the other hand, group B was for familiarization with nature, resting, visit for culture, and looking at scenery, and group $\mathrm{C}$ was for visit for health, playing with children, and events, so they had rather weak purpose of utilizing and were multi-functional use spaces for various utilities. It was clarified that the cultural facilities, sightseeing facilities, and resting facilities in group B were static use spaces and that facilities for artificial landscape; play lot and barbecue lot in group $\mathrm{C}$ were dynamic use spaces.

Further study, on the basis of activity pattern of each unit space, showed that the free open space and waterfront in the unit space of open space system were in a position of multi-functional use space suitable for various use forms and were classified into dynamic or static type of utilizable space in accordance to the physical character. Forest can also be regarded largely, even if a little dependent on 
stand density, as passage type of single-functionally utilizable space in which staying type of utility is restrained. Some forest was subjected to utilizing resting type or nature contact type. In fact, the unit spaces of facilities had a strong purpose of utilization, and had single-function of utilizing the spaces concerned with contents of facilities. The unit space in which the open space became its subject, however, had the finality of users' activities weakened and took on the multi-functional use type of space.

Administration of the unit space and development direction in future based on utilization activities of each unit space from the mutual relation between results of assessment and the physical character observed. Despite fact that free open space and waterfront, which are staying type of multi-functional use space, and the space whose terrain is flat and size is larger than 1ha, is positioned in a type of dynamic space. It was shown that its dynamic utilization is restrained in the sloped terrain or small space, and that it is positioned in a type of statically use space. It is reported that the existence of waterfront promotes the utilization of resting type, and that the existence of waterfront with highly natural property promotes the utilization of the type of nature-contact. It is shown that play lot, barbecue lot, facilities for artificial landscape are dynamically utilizable spaces, and cultural facilities, resting facilities and sightseeing facilities are statically utilizable spaces out of the unit spaces of facilities. It is also shown that amusement facilities are amusement type of use spaces and educational facilities are educational type of use spaces out of the unit spaces of single-functional use spaces.

\section{Conclusions}

To assess the recreational value of all sorts of unit spaces making up urban parks and explore the physical factor concerned with the assessment, the comprehensive interpretation was made of eleven unit spaces of the open spaces and eight unit spaces of the facilities in relation to users' cognitive assessment with the approach to it from the psychological aspect. As a result, the conclusions were drawn as follows:

Overall, the form of the unit space making up the parks existing in the urban area was found to be a user-oriented type, and its availability becomes an important assessment factor with this reflected. As a consequence of inquiring into the comprehensive comfortableness becoming the key point of the assessment, it was found that the recreational value of the forest was low in comparison with that of the unit space of the facilities, the free open space and the waterfront of open space. It was also found that the recreational value of the unit space of the facilities as well as free open space and waterfront ranged from moderate values to high values in response to the physical character of unit space. Open space occupies predominant proportion in the unit space of the facilities, and high technique of planting for artificial landscape considerably improves its recreational value.

The degree of freedom is high in using free open space and waterfront, and the size of the flat and vast space enhances their recreational value appreciably. Arbors develop in the woodland whose assessed value is relatively low, but the feelings of luxuriant forest whose forest floor is arranged. Arbors developed and enhanced its value, and the tall herbaceous-forest preventing users from using the forest degraded its value remarkably.

In order to make clear the position based on the utilization activity of each unit space and present the direction and task for its management and preparation techniques, the findings of assessing the purpose of use were taken together as the approach to it from the behavioral aspect.

For the unit space of the open spaces, the following findings were obtained. Free open space and waterfront are considered as the multi-functional type of use-space appropriate for the form of diverse use of the sojourn type.

It is possible to classify the use-spaces into dynamic activity type and static activity type in accordance with topography and space size. The presence of waterfront within the space improves its use of leisure type and of nature contact type. The important tasks in the free open space include the setting of space size and topographic slant; the introduction of ground-cover vegetation and its maintenance, especially, the important tasks in the waterfront include water behavior, embankment form and its material. If the stand density is less than two per $100 \mathrm{~m}^{2}$ in the forest or woodland, it has 
the function equal to the space of the open space type. If the stand density becomes more than five per $100 \mathrm{~m}^{2}$, the forest can serve as leisure-type use or nature-contact type use, which will make it inhibit sojourn-type use and take on a character of the passage-type space. The important tasks in the forest include the planting design and management techniques relating to the composition of vegetation such as the height and stand density of arbors, and cover type. In particular, in order to activate forest use, the management of forest floor and the cultivation of arbors become its significant tasks.

As for the unit space of the facilities, the following findings were obtained. Because the outdoor recreational value of the unit spaces of the facilities arises from the mutual-contract use between people and the green environment, it is thought desirably that the unit spaces of the facilities becomes the secondary existence supporting the open space in the unit space. The unit space of the facilities in which the open space becomes its subject has the finality of users' activities weakened and takes on the multi-functional use type of space. The unit space centering on the artificial structure is very strong finality and takes on the single use type of space in accordance with the character of facilities. The critical tasks in those spaces include the establishment of the facility size appropriate for the size of space and afforestation for arranging landscape in consideration of its usability with natural elements around.

\section{Acknowledgments}

This paper is supported by National Natural Science Foundation of China (No. 51008282) and Zhejiang Provincial Natural Science Foundation of China (No. LY12E08023).

\section{References}

[1] Kayden, J.S. Privately owned public space: The New York City Experience. Simon \& Schuster, New York, 2002

[2] Akbar, K.F., Hale, W.H.G., Headley, A.D. Assessment of scenic beauty of the roadside vegetation in northern England. Landscape and Urban planning, 63 (2003) 139-144.

[3] Craik, K.H. The assessment of places. In: P. McReynolds (ed.), Advances in Psychological Assessment: Science and Behaviour, Vol. 2, Palo Alto, California, pp. 40-62, 1971.

[4] Dearden, P. Public participation and scenic quality analysis, Landscape Planning, 8 (1981) 3-19.

[5] Loder and Bayly Consulting Group. Visual assessment of south-east Queensland Consultants' report to Open Space and Recreation Program, SEQ2001 project. In: Regional Planning Advisory Group (ed.) Open Space and Recreation, July 1993, SEQ2001 project, Brisbane, 1993.

[6] Rutledge, A.J. A visual approach to park design. Garland STPM Press, New York, 1981. 